${ }^{1}$ Agriculture University of Szczecin, Department of Ruminants Science, Poland
${ }^{2}$ Agriculture University of Poznan, Department of Genetics and Animal Breeding, Poland

ANDRZEJ DYBUS ${ }^{1}$, WILHELM GRZESIAK ${ }^{1}$, HENRYK KAMIENIECKI ${ }^{1}$, IWONA SZATKOWSKA ${ }^{1}$, ZBIGNIEW SOBEK ${ }^{2}$, PIOTR BŁASZCZYK ${ }^{1}$, EWA CZERNIAWSKAPIĄTKOWSKA ${ }^{1}$, SŁAWOMIR ZYCH ${ }^{1}$ and MAGDALENA MUSZYŃSKA ${ }^{1}$

\title{
Association of genetic variants of bovine prolactin with milk production traits of Black-and-White and Jersey cattle
}

\begin{abstract}
Associations between polymorphism localised in the third exon of the prolactin gene (PRL-RsaI) and milk production traits of Black-and-White and Jersey cattle were analysed. A total of 427 cows were included in the study. PCR-RFLP method was used. The frequencies of genotypes and alleles were as follows: $0.7107-A A$, $0.2851-A B, 0.0042$ - BB; $0.8533-P R L^{A}$ and $0.1467-P R L^{B}$ for Black-and-White cattle and $0.0919-A A, 0.4324$ - $A B, 0.4757$ - BB; $0.3081-P R L^{A}$ and $0.6919-P R L^{B}$ for Jersey cattle. Statistically significant differences between the breeds were observed in the frequencies of genotypes and alleles. Associations between PRL-RsaI polymorphism and milk production traits of Jersey cows and lack of associations with these traits in Black-andWhite cows were observed.
\end{abstract}

Key Words: prolactin gene, PCR-RFLP, dairy cattle, milk production traits, Black and White cattle, Jersey

\section{Zusammenfassung}

Titel der Arbeit: Zusammenhänge zwischen den genetischen Prolaktin-Varianten und den Leistungsmerkmalen des Schwarzbunten und Jersey Rindes

Zusammenhänge zwischen dem im dritten Exon des Prolaktin-Gens lokalisierten Polymorphismus (PRL-Rsal) und den Leistungsmerkmalen des Schwarzbunten und Jersey Rindes wurden analysiert. Die Untersuchungen umfassten 427 Kühe. Es wurde die PCR-RFLP-Methode angewandt. Folgende Genotypen und Allelfrequenzen wurden ermittelt: 0,7107 - $A A, 0,2851$ - $A B, 0,0042$ - BB; 0,8533 - $P R L^{A}, 0,1467-P R L^{B}$ für das Schwarzbunte Rind und 0,0919 - $A A, 0,4324-A B, 0,4757-B B ; 0,3081-P R L^{A}, 0,6919-P R L^{B}$ für die Rasse Jersey. Signifikante Unterschiede zwischen Genotyp und Allelfrequenz der untersuchten Rassen konnten festgestellt werden. Zusammenhänge zwischen dem PRL-RsaI-Polymorphismus und den Milchleistungsmerkmalen wurden bei Jersey Kühen beobachtet, hingegen fehlten diese beim Schwarzbunten Rind. .

Schlüsselwörter: Prolaktin, PCR-RFLP, Milchrind, Milchproduktionsmerkmale, Schwarzbunte Rasse, Jersey

\section{Introduction}

Prolactin (PRL) is one of the most versatile hormones of the pituitary gland in terms of biological actions. More than 100 different and distinct effects of the hormone have been documented. In most mammalian species, the hormone consists of 197-199 amino acids (SINHA, 1995). Bovine PRL consists 199 amino acids (WALLIS, 1974). Prolactin is essential for the initiation and maintenance of lactation. It acts on mammary alveoli to promote the synthesis and secretion of milk protein. This hormone is, primarily responsible for the synthesis of milk proteins, lactose and lipids, all major components of milk (LE PROVOST et al., 1994). PRL secretion is maintained during lactation by suckling, the most powerful natural stimulus for PRL release (MURAI and BEN-JONATHAN, 1987). PRL regulating reproductive and immunological functions, fluid balance, cellular growth and differentiation (NICOLL, 
1980; LORETZ and BERN, 1982; RUSSELL, 1989; KELLY et al., 1991). In addition, members of PRL family have been implicated recently as potential regulators of angiogenesis (CLAPP et al., 1998). Prolactin (PRL) gene is expressed in the pituitary gland, and at several other sites including the central nervous system, the immune system and the mammary gland (SINHA, 1995; BEN-JONATHAN et al., 1996; LE PROVOST et al., 1994).

Bovine prolactin (PRL) gene is localised in chromosome 23 (BARENDSE et al., 1997), and consists of five exons separated by interval introns (CAMPER et al., 1984). COWAN et al., (1990) detected a polymorphic site for AvaII restriction endonuclease. Digestion of genomic DNA with the restriction endonuclease AvaII disclosed a probable insertion/deletion of approximately 200 base pairs near the $P R L$ gene. In the studies carried out by HART et al., (1993) showed a four-allele SSCP in the 5'flanking region of the PRL gene. KLAUZIŃSKA et al., (2001) reported the single nucleotide substitutions in the 5' region of the $P R L$ gene. One of these variable sites are also potential binding site for C/EBP transcription factor. A silent A-G transition mutation at the codon for amino acid 103 in exon 3 of bovine $P R L$ gene gives rise to a polymorphic RsaI site (LEWIN et al., 1992). CHUNG et al. (1996) showed that $P R L-$ RsaI locus had a significant effect on milk yield and fat percentage in dairy cattle. In the study carried out by DYBUS (2002) showed that cows with the $A A$ genotypes of the $P R L$ gene had higher milk protein content than $A B$ individuals.

\section{Table 1}

Characterisation of the investigated populations of dairy cows (Charakteristik der untersuchten Milchkuhpopulationen)

\begin{tabular}{|c|c|c|c|c|c|c|c|c|c|c|}
\hline \multirow[t]{2}{*}{ Lactation } & \multirow[t]{2}{*}{ Herd/Breed } & \multirow[t]{2}{*}{$\mathrm{n}$} & \multicolumn{2}{|c|}{$\begin{array}{l}\text { Averege share } \\
\text { of HF genes }\end{array}$} & \multicolumn{2}{|c|}{$\begin{array}{l}\text { Milk yield } \\
\quad(\mathrm{kg})\end{array}$} & \multicolumn{2}{|c|}{$\begin{array}{l}\text { Fat } \\
(\%)\end{array}$} & \multicolumn{2}{|c|}{$\begin{array}{l}\text { Protein } \\
\text { (\%) }\end{array}$} \\
\hline & & & $\bar{x}$ & SD & $\bar{x}$ & SD & $\bar{x}$ & SD & $\bar{x}$ & SD \\
\hline \multirow{3}{*}{ I } & $\begin{array}{c}1^{\text {st }} \\
\text { Black\&White }\end{array}$ & 126 & 0.78 & 0.09 & 7548 & 927 & 4.24 & 0.48 & 3.22 & 0.18 \\
\hline & $\begin{array}{c}2^{\text {nd }} \\
\text { Black\&White }\end{array}$ & 116 & 0.76 & 0.11 & 6173 & 1156 & 4.23 & 0.41 & 3.27 & 0.20 \\
\hline & Jersey & 185 & - & - & 3996 & 663 & 5.62 & 0.53 & 3.87 & 0.22 \\
\hline \multirow{3}{*}{ II } & $\begin{array}{c}1 \text { st } \\
\text { Black\&White }\end{array}$ & 87 & 0.76 & 0.09 & 7263 & 1218 & 4.27 & 0.50 & 3.37 & 0.25 \\
\hline & $\begin{array}{c}\text { 2nd } \\
\text { Black\&White }\end{array}$ & 75 & 0.75 & 0.13 & 6982 & 1380 & 4.37 & 0.41 & 3.29 & 0.18 \\
\hline & Jersey & 147 & - & & 4491 & 638 & 5.72 & 0.56 & 4.00 & 0.24 \\
\hline \multirow{3}{*}{ III } & $\begin{array}{c}\text { 1st } \\
\text { Black\&White }\end{array}$ & 55 & 0.73 & 0.10 & 7727 & 979 & 4.27 & 0.51 & 3.26 & 0.20 \\
\hline & $\begin{array}{c}\text { 2nd } \\
\text { Black\&White }\end{array}$ & 39 & 0.73 & 0.13 & 7890 & 1242 & 4.41 & 0.37 & 3.25 & 0.20 \\
\hline & Jersey & 91 & - & & 4889 & 743 & 5.71 & 0.59 & 4.00 & 0.22 \\
\hline
\end{tabular}


The aim of this study was to estimate the allelic frequencies at the $P R L-R s a I$ locus and to investigate the relationship of this polymorphism and milk production traits of Black-and-White and Jersey cows.

\section{Materials and methods}

A total of 242 Black\&White cows (with different proportional share of HF genes) and 185 pure-bred Jersey cows were genotyped. The B\&W cows were kept in two herds in West Pomerania region of Poland; Jersey cows were kept in the one herd in the Central region of Poland (Table 1).

The PRL-RsaI genotypes were analysed using the PCR-RFLP method (MITRA et al., 1995). Crude DNA was isolated from whoole blood samples using MasterPure ${ }^{\mathrm{TM}}$ kit (Epicentre Technologies). A 156-base pair (bp) fragment of the PRL gene was amplified by polymerase chain reaction (PCR) using forward (5'CGAGTCCTTATGAGCTTGATTCTT-3') and reverse (5'-GCCTTCCAGAAGTCGT TTGTTTTC-3') primers. The PCR reaction contained 80 ng of genomic DNA, 10 pmol of each primer, 1,5 $\mu \mathrm{l} 10$ x PCR buffer (MBI Fermentas), $1.5 \mathrm{mM} \mathrm{MgCl}$, 200 $\mu \mathrm{M}$ dNTP and 0.4 units Taq-polymerase in a total volume of $15 \mu$. The following cycles were applied: denaturation - $94{ }^{\circ} \mathrm{C} / 5 \mathrm{~min}$, followed by 30 cycles - $94{ }^{\circ} \mathrm{C} / 30$ sec, primer anneling $-59{ }^{\circ} \mathrm{C} / 40 \mathrm{sec}$, PCR products synthesis - $72{ }^{\circ} \mathrm{C} / 20 \mathrm{sec}$, and final synthesis - $72{ }^{\circ} \mathrm{C} / 3$ min using a DNA thermal cycler (Perkin Elmer 2400). Amplified DNA was digested with 5 units of RsaI enzyme (MBI Fermentas). The digestion products were separated by horizontal electrophoresis (90 volts, 50 minutes) through $4 \%$ agarose gels (Gibco BRL) in $1 \mathrm{x}$ TBE and $1.0 \mu \mathrm{M}$ ethidium bromide.

Data for 305-day milk production in the first, second and third lactation, including production of milk $(\mathrm{kg})$, milk fat and milk protein $(\mathrm{kg})$ and proportions of milk fat, milk protein and sum of milk fat and protein (\%), were obtained from the farm documentation. Statistical calculations were performed using procedures of Statistica (StatSoft Inc 2001). Distribution frequencies of alleles and genotypes were compared using chi-square test. The effect of $P R L-R s a I$ genotypes on the milk production traits of dairy cows were analysed using General Linear Model (GLM) procedure. Type III ANOVA was used to determine the differences between parameters. Differences of means were testes with the multiple Duncan test. The models used were as follows:

1. Black-and-White cows:

$Y_{i j k l m n o p}=\mu+G_{i}+S_{i}+Y_{k}+Y S_{l}+b_{1}\left(x_{m}-A\right)_{m}+b_{2}\left(x_{n}-H F\right)_{n}+b_{3}\left(x_{o}-D D\right)_{o}+e_{i j k l m n o p}$

$Y_{i j k l m n o p}$ - analysed trait, $G_{i}$ - genotype ( $i=1, \ldots 3$, fixed effect), $S_{i}$ - sire (random effect), $Y_{k}$-year of birth ( $k=1, \ldots 8$, fixed effect), $Y S_{l}$ - year/season $\left(l=1, \ldots 29\right.$, fixed effect), $b_{1}$-regression coefficient of calving age, $A$ - mean of calving age, $x_{m}$-calving age in month of cow, $b_{2}$ - regression coefficient of $H F$ genes, $H F-$ mean percentage of HF genes, $x_{n}$ - percentage of HF genes of cow, $b_{3}$-regression coefficient of days in milk, $D D$ - mean days in milk, $x_{o}-$ days in milk of cow, $e_{i j k l m n o p}$-random error

2. Jersey cows:

$Y_{i j k l m n}=\mu+G_{i}+S_{j}+b_{1}\left(x_{k}-A\right)_{k}+b_{2}\left(x_{l}-D D\right)_{l}+Y S_{m}+e_{i j k l m n}$

$Y_{i j k l m n}$ - analysed trait, $\mu$ - overall mean, $G_{i}$ - genotype ( $i=1, \ldots 3$, fixed effect), $S_{j}$ - sire (random effect), $b_{1}$ - regression coefficient of calving age, $A$ - mean of calving age, $x_{k}-$ calving age in month of cow, $b_{2}$ - regression coefficient of days in milk, DD - mean days in milk, $x_{l}$ - days in milk of cow $Y S_{m}$ -year-season $\left(l=1, \ldots 39\right.$, fixed effect), $x$ - trait mean, $e_{i j k l m n}$ - random error. 


\section{Results}

The following DNA restriction fragments were obtained for the $P R L-R s a \mathrm{I}$ polymorphism: 82 and 74 bp for the $B B$ genotype, 156, 82 and 74 bp for the $A B$ and 156 bp (no digestion) for the $A A$ (Fig.).

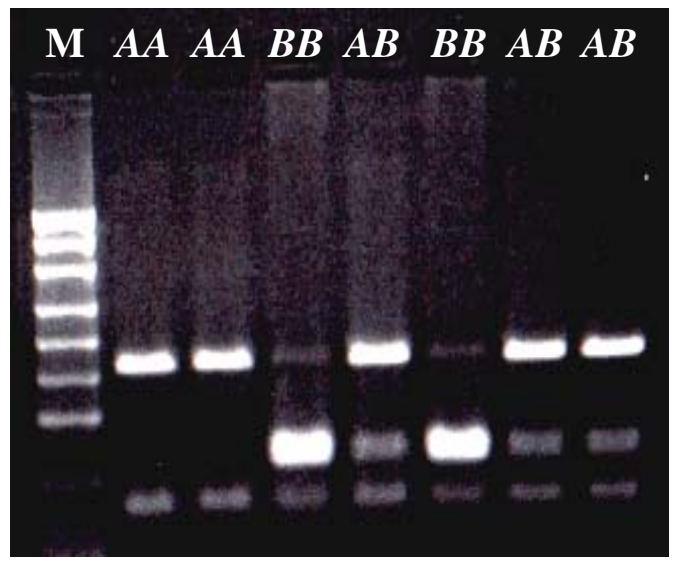

Figure: Representative results of $P R L-R s a \mathrm{I}$ analysis detected by agarose gel electrophoresis (Elektrophoretische Trennung von Restriktionsfragmenten $P R L-R s a \mathrm{I})$

M - DNA marker (pUC19/MspI)

In Black-and-White cattle the $A A$ genotype was the most frequent in the studied herds (0.7222 and 0.6983$)$, followed by the heterozygotic $A B(0.2778$ and 0.2931$)$, whereas the $B B$ was the least frequent $(0$ and 0.0086$)$. In contrary, in Jersey cows the $B B$ genotype was the most frequent (Table 2).

Table 3 shows the influence of the $P R L-R s a I$ polymorphism on milk production traits in Jersey cows.

Table 4 shows the influence of the $P R L-R s a I$ polymorphism on milk production traits in Black-and-White cows

Table 2

Frequencies of genotypes and alleles of the PRL-RsaI (Frequenz von Genotypen und Allelen von $P R L-R s a \mathrm{I}$ )

\begin{tabular}{c|c|c|c|c|c|c}
\hline \multirow{2}{*}{ Herd } & \multirow{2}{*}{$\mathrm{n}$} & \multicolumn{3}{|c|}{ Genotypes PRL-RsaI } & \multicolumn{2}{c}{ Alleles } \\
\cline { 3 - 7 } & & $A A$ & $A B$ & $B B$ & $P R L^{A}$ & $P R L^{B}$ \\
\hline $1^{\text {st }}$ Black-and-White & 126 & 0.7222 & 0.2778 & - & 0.8611 & 0.1389 \\
\hline $2^{\text {nd }}$ Black-and-White & 116 & 0.6983 & 0.2931 & 0.0086 & 0.8449 & 0.1552 \\
\hline Total Black\&White & 242 & 0.7107 & 0.2851 & 0.0042 & 0.8533 & 0.1467 \\
\hline Jersey & 185 & 0.0919 & 0.4324 & 0.4757 & 0.3081 & 0.6919 \\
\hline
\end{tabular}


Table 3

Means and standard deviations of milk production traits in Jersey cows carrying different $P R L-R s a$ I genotypes (Mittelwerte und Standardabweichungen der Milchleistungsmerkmale bei Jersey Kühen mit verschiedenen Genotypen $P R L-R s a \mathrm{I})$

\begin{tabular}{|c|c|c|c|c|c|c|c|c|c|c|c|c|c|c|}
\hline \multirow[t]{2}{*}{$\mathrm{L}$} & \multirow[t]{2}{*}{ Gen } & \multirow{2}{*}{$\mathrm{n}$} & \multicolumn{2}{|c|}{$\begin{array}{l}\text { Milk yield } \\
\quad(\mathrm{kg})\end{array}$} & \multicolumn{2}{|c|}{$\begin{array}{l}\text { Fat } \\
\text { (kg) }\end{array}$} & \multicolumn{2}{|c|}{$\begin{array}{l}\text { Fat } \\
(\%)\end{array}$} & \multicolumn{2}{|c|}{$\begin{array}{l}\text { Protein } \\
\text { (kg) }\end{array}$} & \multicolumn{2}{|c|}{$\begin{array}{c}\text { Protein } \\
\text { (\%) }\end{array}$} & \multicolumn{2}{|c|}{$\begin{array}{c}\text { F\&P } \\
(\%)\end{array}$} \\
\hline & & & $\bar{x}$ & SD & $\bar{x}$ & SD & $\bar{x}$ & SD & $\bar{x}$ & SD & $\bar{x}$ & SD & $\bar{x}$ & SD \\
\hline \multirow{3}{*}{$1^{\mathrm{st}}$} & $A A$ & 17 & 3840 & 701 & $209.2^{\mathrm{AB}}$ & 40 & $5.45^{\mathrm{ab}}$ & 0.50 & 147.5 & 24 & 3.86 & 0.20 & 9.31 & 0.59 \\
\hline & $A B$ & 80 & 4013 & 597 & $225.1^{\mathrm{A}}$ & 31 & $5.64^{\mathrm{a}}$ & 0.48 & 155.3 & 21 & 3.87 & 0.21 & 9.51 & 0.60 \\
\hline & $B B$ & 88 & 4011 & 715 & $223.8^{B}$ & 37 & $5.63^{b}$ & 0.60 & 154.4 & 24 & 3.86 & 0.30 & 9.49 & 0.81 \\
\hline \multirow{3}{*}{$2^{\text {nd }}$} & $A A$ & 13 & 4634 & 960 & 261.2 & 54 & 5.68 & 0.67 & 184.9 & 35 & 4.00 & 0.18 & 9.68 & 0.74 \\
\hline & $A B$ & 63 & 4388 & 576 & 254.2 & 35 & 5.82 & 0.49 & 177.0 & 23 & 4.04 & 0.22 & 9.86 & 0.64 \\
\hline & $B B$ & 71 & 4557 & 617 & 255.6 & 34 & 5.64 & 0.59 & 180.1 & 22 & 3.96 & 0.26 & 9.60 & 0.78 \\
\hline \multirow{3}{*}{$3^{\text {rd }}$} & $A A$ & 6 & 4991 & 701 & 270.3 & 39 & 5.48 & 0.90 & 194.8 & 26 & 3.91 & 0.22 & $9.39^{\mathrm{a}}$ & 1.08 \\
\hline & $A B$ & 37 & 4805 & 764 & 276.2 & 41 & 5.77 & 0.47 & 194.6 & 30 & 4.06 & 0.18 & $9.83^{\mathrm{a}}$ & 0.61 \\
\hline & $B B$ & 48 & 4949 & 739 & 279.9 & 39 & 5.69 & 0.63 & 195.9 & 25 & 3.98 & 0.24 & 9.67 & 0.80 \\
\hline
\end{tabular}

Frequencies in columns with the same letter differ significantly; capitals $\mathrm{P} \leq 0.01$, small letters $\mathrm{P} \leq 0.05$;

$\mathrm{n}$ - number of cows; F\&P - sum of fat\&protein content; L - lactation; Gen - genotype; SD - standard deviation

Table 4

Means and standard deviations of milk production traits in Black\&White cows carrying different $P R L-R s a \mathrm{I}$ genotypes (Mittelwerte und Standardabweichungen der Milchleistungsmerkmale bei schwarzbunten Kühen mit verschiedenen Genotypen $P R L-R s a \mathrm{I})$

\begin{tabular}{|c|c|c|c|c|c|c|c|c|c|c|c|c|c|c|}
\hline \multirow[t]{2}{*}{$\mathrm{L}$} & \multirow[t]{2}{*}{ Gen } & \multirow[t]{2}{*}{$\mathrm{n}$} & \multicolumn{2}{|c|}{$\begin{array}{l}\text { Milk yield } \\
\text { (kg) }\end{array}$} & \multicolumn{2}{|c|}{$\begin{array}{l}\text { Fat } \\
(\mathrm{kg})\end{array}$} & \multicolumn{2}{|c|}{$\begin{array}{l}\text { Fat } \\
(\%)\end{array}$} & \multicolumn{2}{|c|}{$\begin{array}{l}\text { Protein } \\
\text { (kg) }\end{array}$} & \multicolumn{2}{|c|}{$\begin{array}{c}\text { Protein } \\
\text { (\%) }\end{array}$} & \multicolumn{2}{|c|}{$\begin{array}{c}\text { F\&P } \\
(\%)\end{array}$} \\
\hline & & & $\bar{x}$ & SD & $\bar{x}$ & SD & $\bar{x}$ & SD & $\bar{x}$ & SD & $\bar{x}$ & SD & $\bar{x}$ & SD \\
\hline \multirow{3}{*}{$1^{\text {st }}$} & $A A$ & 172 & 6896 & 1284 & 295.1 & 62 & 4.28 & 0.44 & 224.1 & 43 & 3.25 & 0.21 & 7.53 & 0.56 \\
\hline & $A B$ & 69 & 6911 & 1131 & 286.8 & 52 & 4.15 & 0.49 & 224.6 & 37 & 3.25 & 0.18 & 7.40 & 0.60 \\
\hline & $B B$ & $1 *$ & 4354 & - & 165.4 & - & 3.80 & - & 130.2 & - & 2.99 & - & 6.79 & - \\
\hline \multirow{3}{*}{$2^{\text {nd }}$} & $A A$ & 117 & 7012 & 1301 & 306.4 & 62 & 4.37 & 0.45 & 234.9 & 44 & 3.35 & 0.23 & 7.72 & 0.57 \\
\hline & $A B$ & 44 & 7472 & 1263 & 313.1 & 65 & 4.19 & 0.48 & 248.8 & 43 & 3.33 & 0.22 & 7.52 & 0.60 \\
\hline & $B B$ & $1^{*}$ & 6466 & - & 272.2 & - & 4.21 & - & 194.6 & - & 3.01 & - & 7.22 & - \\
\hline \multirow{3}{*}{$3^{\text {rd }}$} & $A A$ & 69 & 7832 & 1091 & 340.7 & 56 & 4.35 & 0.51 & 256.9 & 36 & 3.28 & 0.21 & 7.63 & 0.64 \\
\hline & $A B$ & 24 & 7732 & 1121 & 330.2 & 57 & 4.27 & 0.35 & 248.2 & 36 & 3.21 & 0.19 & 7.48 & 0.46 \\
\hline & $B B$ & $1^{*}$ & 6810 & - & 307.1 & - & 4.51 & - & 225.4 & - & 3.31 & - & 7.82 & - \\
\hline
\end{tabular}

Frequencies in columns with the same letter differ significantly; capitals $\mathrm{P} \leq 0.01$, small letters $\mathrm{P} \leq 0.05$;

$\mathrm{n}$ - number of cows; F\&P - sum of fat and protein content, * - excluded from the statistical analysis

\section{Discussion}

In dairy cattle, the primary goal of the selection is the improvement of yield and composition of milk. With the advances in molecular biology, the identification of the genes underlying livestock production traits - called quantitative trait loci (QTL) - is now possible and is likely to lead to more efficient breeding programs (PARMENTIER et al., 1999). Although a number of strategies can be envisaged to identify candidate genes markers, essentially two approaches are presently developed to estimate the favourable QTL implicated in a specific production trait. The first 
method, the positional cloning, consist of the localization of the genes of interest using marker-QTL associations covering the whole genome. The second strategy uses the candidate gene approach (COPPIETERS et al., 1999; SCHALKWYK et al., 1999; SEYFERT, 1999). GRUPE and SCHWERIN (1998) mapped QTL, affecting milk yield and milk fat content, on the telomeric region of bovine chromosome 23.

The genetic equilibrium in the populations under study was not disturbed and the size of certain genotypes of the $P R L$ was not statistically different from the theoretically calculated size. Frequencies of $P R L-R s a I$ alleles obtained in this study were similar to the frequencies obtained earlier for the Black\&White cattle. Higher frequency of the $P R L^{A}$ (0.95) in Holstein breed was observed by CHRENEK et al. (1998). Somewhat smaller frequency of the $P R L^{A}(0.80)$ was observed in studies of MITRA et al. (1995). Considerably smaller frequencies of $P R L^{A}(0.73)$ were observed by CHUNG et al. (1996). The frequencies of $P R L-R s a I$ alleles found in this study for Jersey cows considerably deviate from the values found for Holstein-Friesian cows. World literature lacks reports on $P R L$-RsaI polymorphism in Jersey cattle, which hinders any inference.

Table 3 shows the influence of the $P R L-R s a$ I polymorphism on milk production traits in the analysed Jersey cows. The statistically significant differences between individuals of different $P R L$ genotypes were found in milk fat yield, milk fat content and and sum of fat and protein content. In the first 305-day lactation, the cows of the $A A$ genotype produced less milk fat (-15.9 and $-14.6 \mathrm{~kg}$ ) than the $A B$ and $B B$ individuals $(\mathrm{P} \leq 0.01)$.

In the case of milk fat content, statistically significant differences between individuals of different $P R L$ genotypes were found in the first lactation $(\mathrm{P} \leq 0.01)$. The cows with the $A A$ genotype produced milk with lower fat content (-0.19 and $-0.18 \%)$ than $A B$ and $B B$ individuals, respectively. Different results were obtained by CHUNG et al., (1996) who reported that Holstein-Friesian cows with $A A$ genotype produced milk with higher fat content than $B B$ individuals. CHRENEK et al. (1999) examined an influence of $P R L-R s a \mathrm{I}$ polymorphism on the milk production traits of Brown Swiss cows, and there were no statistically significant differences between the cows with different $P R L$ genotype.

In reference to sum of milk fat and protein (\%), statistically significant differences $(\mathrm{P} \leq 0.01)$ between the cows with different $P R L$-RsaI genotype were observed. In the third lactation cows with $A B$ genotype had higher F\&P content $(+0.44 \%)$ than $A A$ individuals.

In our study, no associations between $R F L P$ in $P R L$ gene and milk production traits were found for Black-and-White cattle. Bearing in mind the weak associations in Jersey cattle and no associations in B\&W cattle, it should be stressed that the usefulness of $P R L$-RsaI polymorphism for the improvement of production traits of dairy cattle seems uncertain.

\section{References}

BARENDSE, W.; VAIMAN, D.; KEMP, S.J.; SUGIMOTO Y.; ARMITAGE, S.M.; WILLIAMS, J.L.; SUN, H.S.; EGGEN, A.; AGABA, M.; ALEYASIN, S.A.; BAND, M.; BISHOP, M.D.; BUITKAMP, J.; BYRNE, K.; COLLINS, F.; COOPER, L.; COPPETTIERS, W.; DENYS, B.; DRINKWATER, R.D.; EASTERDAY, K.; ELDUQUE, C.; ENNIS, S.; ERHARDT, G.; FERRETTI, L.; FLAVIN, N.; GAO, Q.; GEORGES, M.; GURUNG, R.; HARLIZIUS, B.; HAWKINS, G.; HETZEL, J.; HIRANO, T.; HULME, D.; JORGENSEN, C.; KESSLER, M.; KIRKPATRICK, B.W.; KONFORTOV, B.; KOSTIA, S.; KUHN, C.; LENSTRA, J.A.; 
LEVEZIEL, H.; LEWIN, H.A.; LEYHE, B.; LIL, L.; MARTIN, BURRIEL, I.; MCGRAW, R.A.; MILLER, J.R.; MOODY, D.E.; MOORE, S.S.; NAKANE, S.; NIJMAN, I.J.; OLSAKER, I.; POMP, D.; RANDO, A.; RON, M.; SHALOM, A.; TEALE, A.J.; THIEVEN, U.; URQUHART, B.G.D.; VAGE, D.-I.; VAN DE WEGHE, A.; VARVIO, S.; VELMALA, R.; VILKKI, J.; WEIKARD, R.; WOODSIDE, C.; WOMACK, J.E.; ZANOTTI, M.; ZARAGOZA, P.:

A medium-density genetic linkage map of the bovine genome. Mammalian Genome, 8 (1997), 21-28

BEN-JONATHAN, N.; MERSHON, J.L.; ALLEN, D.I.; STEINMETZ, R.W.:

Extrapituitary prolactin: distribution, regulation, functions, and clinical aspects. Endocrine Review, 17 (1996), 639-669

CAMPER, S.A.; LUCK, D.N.; YAO, Y.; WOYCHIK, R.P.; GOODWIN, R.G.; LYONS, R.H.; ROTTMAN, F.M.:

Characterization of the bovine prolactin gene. DNA, 3 (1984), 237-249

CHRENEK, P.; HUBA, J.; ORAVCOVA, M.; HETENYI, L.; PESKOVIEOVA, D.; BULLA, J.:

Genotypes of bGH and bPRL genes in relationships to milk production. EAAP $-50^{\text {th }}$ Annual Meeting, Zurich, Book of Abstracts (1999), 40

CHRENEK, P., VASICEK, D., BAUEROVA, M., BULLA, J.:

Simultaneous analysis of bovine growth hormone and prolactin alleles by multiplex PCR and RFPL. Czech Journal of Animal Science, 43 (1998), 53-55

CHUNG, E.R., RHIM, T.J., HAN, S.K.:

Associations between PCR-RFLP markers of growth hormone and prolactin genes and production traits in dairy cattle. Korean Journal of Animal Science, 38 (1996), 321-336

CLAPP, C.; LOPEZ-GOMEZ, F.J.; NAVA, G.; CORBACHO, A.; TORNER, L.; MACOTELA, Y.; DUENAS,

Z.; OCHOA, A.; NORIS, G.; ACOSTA, E.; GARAY, E.; MARTINEZ DE LA ESCALERA, G.:

Expression of prolactin mRNA and of prolactin-like proteins in endothelial cells: evidence for autocrine effects. Journal of Endocrinology, 158 (1998), 137-144

COPPIETERS, W.; BLOTT, S.; FARNIR, F.; GRISART, B.; RIQUET, J.; GEORGES, M.:

From phenotype to genotype: towards positional cloning of QTL in livestock? Arch. Tierz., Dummerstorf 42 (1999) Special Issue, 86-92

COWAN, C.M.; DENTINE, M.R.; AX, R.L.; SCHULER, L.A.:

Structural variation around prolactin gene linked to quantitative traits in an elite Holstein sire family. Theoretical and Applied Genetics, 79 (1990), 577-582

DYBUS, A.:

Associations of growth hormone (GH) and prolactin (PRL) genes polymorphisms with milk production traits in polish Black-and-White cattle. Animal Science Papers and Reports, 20 (2002), 203-212

GRUPE, S.; SCHWERIN, M.:

Mapping of quantitative trait loci on chromosome 23 in German Holstein Friesian cattle families. Arch. Tierz., Dummerstorf 41 (1998), 225-235

HART, G.L.; BASTIAANSEN, J.; DENTINE, M.R.; KIRKPATRICK, B.W.:

Detection of a four-allele single strand conformation polymorphism (SSCP) in the bovine prolactin gene 5’ flank. Animal Genetics, 24 (1993), 149

KELLY, P.A.; DJIANE, J.; POSTEL-VINAY, M.C.; EDERY, M.:

The prolactin/growth hormone receptor family. Endocrine Review 12 (1991), 235-251

KLAUZIŃSKA, M.; GROCHOWSKA, R.; ZWIERZCHOWSKI, L.:

Polymorphism of the 5'-flanking regions of the prolactin and growth hormone receptor genes of cattle. $14^{\mathrm{TH}}$ Congress of Polish Genetics Society, Book of Abstracts, (2001), 84

LE PROVOST, F.; LEROUX, C.; MARTIN, P.; GAYE, P.; DIJANE J.:

Prolactin gene expression in ovine and caprine mammary gland. Neuroendocrinology, 60 (1994), 305313

LEWIN, H.A.; SCHMITT, K.; HUBERT, R.; VAN EIJK, M.J., ARNHEIM, N.:

Close linkage between bovine prolactin and BoLA-DRB3 genes: genetic mapping in cattle by single sperm typing. Genomics, 13 (1992), 44-48

LORETZ, C.A.; BERN, H.A.:

Prolactin and osmoregulation in vertebrates. Neuroendocrinology, 35 (1982), 292-304

MITRA, A.; SCHLEE, P.; BALAKRISHNAN, C.R.; PIRCHNER, F.:

Polymorphisms at growth-hormone and prolactin loci in Indian cattle and buffalo. Journal of Animal Breeding and Genetics, 112 (1995), 71-74

MURAI, I.; BEN-JONATHAN, N.:

Posterior pituitary lobectomy abolishes the suckling-induced rise in prolactin (PRL): evidence for a PRL-releasing factor in the posterior pituitary. Endocrinology, 121 (1987), 205-211

NICOLL, C.S.:

Ontogeny and evolution of prolactin’s functions. FASEB Journal, 39 (1980), 2563-2566 
PARMENTIER, I.; PORTETELLE, D.; GENGLER, N.; PRANDI, A.; BERTOZZI, C.; VLEURICK, L.; GILSON, R.; RENAVILLE, R.:

Candidate gene markers associated with somatotropic axis and milk selection. Domestic Animal Endocrinology, 17 (1999), 139-148

RUSSELL, D.H.:

New aspects of prolactin and immunity: a lymphocyte-derived prolactin like product and nuclear protein kinase C activation. Trends in Farmacological Science, 10 (1989), 40-44

SCHALKWYK, J.C.; HIMMELBAUER, H.; LEHRACH, H.:

Towards the mammalian transcript map. Arch. Tierz., Dummerstorf 42 (1999) Special Issue, 67-73

SEYFERT, H.M.:

Lactoferrin and Lysozyme - Two mammalian antibiotics. Arch. Tierz., Dummerstorf 42 (1999) Special Issue, 22-27

SINHA, Y.N.:

Structural variants of prolactin: occurrence and physiological significance. Endocrine Review, 16 (1995), 354-369

STATSOFT, INC:

Statistica (data analysis software system), v. 6 (2001), www.statsoft.com

WALLIS, M.:

The primary structure of bovine prolactin. Federation of European Biochemical Societies Letters, 44 (1974), 205-208

Received: 2004-04-06

Accepted: 2005-03-14

Corresponding author

ANDRZEJ DYBUS, PhD

Agriculture University of Szczecin

Department of Ruminants Science

Doktora Judyma 12, 71-460 Szczecin, Poland

E-mail: a.dybus@biot.ar.szczecin.pl 